\title{
Effect of Non-genetic Factors on Performance Traits of Murrah Buffaloes: Review
}

\author{
Vikram Jakhar ${ }^{1}$, A.K. Vinayak ${ }^{1}$ and K.P. Singh ${ }^{2}$ \\ ${ }^{1}$ Department of Animal Genetics and Breeding, LUVAS, Hisar, Haryana, India \\ ${ }^{2}$ ICAR-Central Institute for Research on Buffaloes, Hisar, Haryana, India \\ *Corresponding author
}

\section{A B S T R A C T}

\section{Keywords}

Non-genetic factors, Traits, Murrah buffaloes.

Article Info

Accepted:

30 October 2017

Available Online:

10 November 2017
The success of a dairy industry in India is much dependent on buffaloes and the level of production and reproduction traits. These performance traits depend on several genetic and non-genetic factors which introduce biasness in the estimation of genetic value of performance traits. In the absence of accurate phenotypic value of milk production traits, it becomes difficult to estimate genetic parameters of the traits which determine the optimum selection criterion for planned improvement programme of the animals. Also genetic evaluation of animals require the assumption that phenotypic measurements are adjusted for non-genetic factors that can affect production efficiency and reproduction traits (ex. Year/period of calving, season of calving, calving order, age at calving, length of lactation) to obtain accurate estimates of the genetic parameters and the breeding value of animals. This review summarizes the means/averages of milk production and reproduction traits, effect of non-genetic factors on performance traits in buffaloes. The production traits reviewed were Total Lactation Milk Yield (TLMY), 305 Day Milk Yield (305DMY), Peak Yield (PY), Lactation Length (LL) and Dry Period (DP). The reproduction traits reviewed were Service Period (SP) and Calving Interval (CI). In order to improve productivity, obtain efficient reproduction and health of dairy animals it is necessary to develop an understanding of the factors affecting milk production, reproduction traits.

\section{Introduction}

Buffaloes are considered as the major dairy animal and backbone of Indian dairy industry. India ranks first in milk production accounting for $18.5 \%$ of worlds' milk production with an annual output of 146.3 million tons resulting in per capita availability of 322 g/day (NDDB, 2014-15). Buffaloes with a population of 108.7 million, the largest in the world, contribute $51.06 \%$ (74.71 million tons) to the total milk production in the country, which is valued for its quality being twice as rich in fat and other milk constituents as compared to the cow milk. Besides this, buffaloes contribute significantly towards meat production, draft power, dung for manure and fuel.

Thus, buffaloes are the most important and indispensable component of livestock sector in the country. The buffalo genetic resources of the country are represented by 13 registered breeds and graded buffalo populations adapted to different ecological niches. Murrah is one of the superior breeds 
of Indian buffaloes with a population of 20.49 million, which constitutes around $65 \%$ of Indian buffaloes of well-defined breeds. owing to its potential, it has short productive period in terms of milk and high unproductive life with longer inter calving period and age at first calving, which may be happened due to several genetic and non-genetic factors like parity, period of calving and season of calving. The situation gets more complicated when environment become harsh and nonsupportive for exploitation of animal fullest potential in term of milk production. Evaluations of genetic value of performance traits require knowledge of several genetic parameters so that suitable breeding schemes can be developed for improvement of this species.

The present breeding goals in the country are primarily focused on increasing milk production and not directed towards the cost effective performance of dairy animals. It is therefore imperative that attempt should be made to consider production and reproduction traits together in genetic improvement programmes. The non-genetic factors such as management, amount and quality of feed, season, period of calving, parity etc. influences these performance traits. Under this background, this review was aimed to evaluate the effects of various non-genetic factors on production and reproduction traits of Murrah buffaloes. This will help to formulate suitable evaluation procedures and selection of superior animals for future generation for improving economic traits of buffaloes.

\section{Averages of milk production and reproduction traits}

The least square means of milk production and reproduction traits reported by various workers in buffaloes are presented in table 1 and 2 , respectively.

\section{Effect of genetic and non-genetic factors on performance traits}

\section{Production traits}

\section{Total lactation milk yield}

Milk yield is the central trait over which whole of the animal improvement programme revolves. Lactation milk yield reflects the real economic worth of the buffalo and is considered as a major performance trait considered in the selection criteria for the genetic improvement of dairy animals and almost all other traits, directly or indirectly associated with it.

A significant effect of period of calving on total lactation milk yield was reported by Yadav et al., (2002), Wakchaure et al., (2008), Jakhar et al., (2016) in Murrah buffaloes. Thiruvenkadan (2011) reported highly significant $(\mathrm{p}<0.01)$ effect of period of calving on TLMY in Murrah buffaloes. Nonsignificant effect of period of calving was also reported Barman (2009), Barman et al., (2012), Pawar et al., (2012) and Kumar et al., (2014) on TLMY in Murrah buffaloes.

TLMY was significantly affected by season of calving was reported by Pawaret al., (2012) and Thiruvenkadan (2011) reported the highly significant $(p<0.01)$ effect of season of calving on TLMY in Murrah buffaloes. Significant effect was also reported by Grewal et al., (2003), Godara et al., (2004), Barman (2009) and Barman et al., (2012) in Murrah buffaloes.

Kumar (2002), Suresh et al., (2004) and Kumar et al., (2014), Jakhar et al., (2016) in Murrah buffaloes reported non- significant effect of season of calving on TLMY. Significant effect of age at calving on TLMY was reported by Gurung and Johar (1982) in Murrah buffaloes, Dhirendra et al., (2003) in 
Murrah buffaloes. However Barman (2009) and Barman et al., (2012) in Murrah buffaloes observed non-significant correlation between age at calving and TLMY. Dhar et al., (1995) revealed highly significant effect of parity on TLMY in Murrah buffaloes. Thiruvenkadan (2011) reported the highly significant ( $<<0.01)$ effect of parity on TLMY in Murrah buffaloes. Jakhar et al., (2016) reported significant $(p<0.01)$ effect of parity of lactation on TLMY in Murrah buffaloes. However Pawar et al., (2012) reported nonsignificant effect of parity on TLMY in Murrah buffaloes.

\section{5 days milk yield}

Gupta et al., (2012) reported the least square means for first lactation 305 day milk yield was $1942.75 \pm 53.79 \mathrm{~kg}(\mathrm{p}<0.01)$ in Murrah buffalo. Highly significant $(\mathrm{p}<0.01)$ effect of period of calving on 305 days milk yield in Murrah buffaloes reported by Thiruvenkadan (2011) and Jakhar et al., (2016). Pawar et al., (2012) observed significant ( $p<0.05)$ effect of season on 305 day milk yield in Murrah buffalo. Thiruvenkadan (2011) and Jakhar et al., (2016) reported highly significant ( $p<0.01$ ) effect of season of calving on 305 days milk yield in Murrah buffaloes.

Non-significant effect of season of calving on 305DMY was reported by Kumar et al., (2014) in Murrah buffaloes. Thiruvenkadan (2011) and Jakhar et al., (2016) reported the highly significant $(p<0.01)$ effect of parity on 305 days milk yield in Murrah buffaloes. Pawar et al., (2012) reported no significant effect of parity on 305 day milk yield.

\section{Peak yield}

Attainment of peak yield reflects manifestation of maximum milk secretion during a day in a lactation. The trait shows considerable variability within breed.
Thiruvenkadan (2011) reported the highly significant $(\mathrm{p}<0.01)$ effect of period of calving on peak yield in Murrah buffaloes.

Thiruvenkadan (2011) reported the highly significant $(p<0.01)$ effect of season of calving on peak yield in Murrah buffaloes. Jakhar et al., (2016) reported the highly significant $(\mathrm{p}<0.01)$ effect of season of calving on peak yield in Murrah buffaloes. Non-significant effect of season of calving was reported by Prakash and Tripathi (1987a) in Murrah buffaloes.

Thiruvenkadan (2011) and Jakhar et al., (2016) reported the highly significant $(p<0.01)$ effect of parity on peak yield in Murrah buffaloes. Significant influence of parity was observed by Prakash and Tripathi (1987b) in Murrah.

\section{Lactation length}

The period from the initiation of production to the day when production stops, in short, the actual productive period is defined as the lactation length. Thiruvenkadan et al., (2010) reported highly significant influence of period of calving on lactation length observed corroborated with previous finding on Murrah buffalo (Suresh et al., 2004). Dhar et al., (1995) reported highly significant influence of period of calving on lactation length in Murrah buffaloes.

Dhar et al., (1995) reported highly significant influence of season of calving on lactation length in Murrah buffaloes. Jakhar et al., (2016) reported highly significant influence of season of calving on lactation length in Murrah buffaloes. Dhar et al., (1995) reported highly significant influence of parity on lactation length in Murrah buffaloes. Jakhar et al., (2016) reported highly significant $(p<0.01)$ effect of parity on LL in Murrah buffaloes. 
Table.1 Means and standard error for production traits of buffaloes

\begin{tabular}{|c|c|c|c|c|c|c|c|}
\hline \multirow[t]{2}{*}{ Sr.No. } & \multirow[t]{2}{*}{ Traits } & \multirow[t]{2}{*}{ Mean \pm SE } & \multirow[t]{2}{*}{$\mathbf{N}$} & \multicolumn{3}{|c|}{ non genetic factors } & \multirow[t]{2}{*}{ references } \\
\hline & & & & period & season & parity & \\
\hline \multirow[t]{5}{*}{1.} & \multirow{5}{*}{\begin{tabular}{lr}
\multicolumn{2}{l}{ Total } \\
Milk & Yielation \\
$(\mathrm{kg})$ &
\end{tabular}} & $1844.99 \pm 21.31$ & 628 & $\mathrm{~S}$ & NS & - & Nath (1998) \\
\hline & & $1997.9 \pm 66.2$ & 1479 & NS & NS & - & Singh et al., (2011) \\
\hline & & $1942.75 \pm 53.79$ & 330 & NS & NS & - & Gupta et al., (2012) \\
\hline & & $1365.08 \pm 2.98$ & 116 & $\mathrm{~S}$ & $\mathrm{~S}$ & - & Pandey et al., (2015) \\
\hline & & $2182.82 \pm 20.19$ & 1637 & $\mathrm{~S}$ & NS & - & Jakhar et al., (2016) \\
\hline \multirow[t]{6}{*}{2.} & \multirow{6}{*}{$\begin{array}{l}305 \text { Day Milk } \\
\text { Yield }(\mathrm{kg})\end{array}$} & $1853.49 \pm 15.88$ & 961 & $\mathrm{~S}$ & $\mathrm{~S}$ & - & Sahoo et al., (2014) \\
\hline & & $1365 \pm 03$ & 113 & $\mathrm{~S}$ & $\mathrm{~S}$ & - & Pandey et al., (2015) \\
\hline & & $2065.76 \pm 41.29$ & 162 & $\mathrm{~S}$ & NS & - & Kumar et al., (2016) \\
\hline & & $2060.93 \pm 20.22$ & 1637 & $\mathrm{~S}$ & NS & - & Jakhar et al., (2016) \\
\hline & & $2078.20 \pm 31.21$ & 154 & $\mathrm{~S}$ & NS & - & Jamuna et al., (2016) \\
\hline & & $1977.9 \pm 36.2$ & 315 & $\mathrm{~S}$ & $\mathrm{~S}$ & - & Chitra et al., (2016) \\
\hline \multirow[t]{4}{*}{3.} & \multirow{4}{*}{$\begin{array}{ll}\text { Peak } & \text { Yield } \\
(\mathrm{kg}) & \end{array}$} & 7.920 .16 & 279 & - & - & - & Kumar(2000) \\
\hline & & 7.92 .016 & 289 & - & - & - & Kumar et al., (2005) \\
\hline & & 10.160 .26 & 326 & - & - & - & Chakraborty et al., (2010) \\
\hline & & 9.090 .07 & 395 & $\mathrm{~S}$ & $\mathrm{~S}$ & $\mathrm{~S}$ & Thiruvenkadan (2011) \\
\hline \multirow[t]{8}{*}{4.} & \multirow{8}{*}{$\begin{array}{l}\text { Lactation } \\
\text { Length (days) }\end{array}$} & $1853.49 \pm 15.88$ & 961 & $\mathrm{~S}$ & $\mathrm{~S}$ & - & Sahoo et al., (2014) \\
\hline & & $1365 \pm 03$ & 113 & $\mathrm{~S}$ & $\mathrm{~S}$ & - & Pandey et al., (2015) \\
\hline & & $2065.76 \pm 41.29$ & 162 & $\mathrm{~S}$ & NS & - & Kumar et al., (2016) \\
\hline & & $2060.93 \pm 20.22$ & 1637 & $\mathrm{~S}$ & NS & - & Jakhar et al., (2016) \\
\hline & & $2078.20 \pm 31.21$ & 154 & $\mathrm{~S}$ & NS & - & Jamuna et al., (2016) \\
\hline & & $1977.9 \pm 36.2$ & 315 & $\mathrm{~S}$ & $\mathrm{~S}$ & - & Chitra et al., (2016) \\
\hline & & $1853.49 \pm 15.88$ & 961 & $\mathrm{~S}$ & $\mathrm{~S}$ & - & Sahoo et al., (2014) \\
\hline & & $1365 \pm 03$ & 113 & $\mathrm{~S}$ & $\mathrm{~S}$ & - & Pandey et al., (2015) \\
\hline \multirow[t]{6}{*}{5.} & \multirow{6}{*}{$\begin{array}{ll}\begin{array}{l}\text { Dry } \\
\text { (days) }\end{array} & \text { period } \\
\end{array}$} & $205.4 \pm 8.7$ & 236 & $\mathrm{~S}$ & NS & - & Tailor et al., (1992) \\
\hline & & $187 \pm 2.2$ & 2107 & - & - & - & Kuralkar and Raheja (1997) \\
\hline & & $164.18 \pm 4.70$ & 1200 & $\mathrm{~S}$ & $\mathrm{~S}$ & - & Wakachaure et al., (2008) \\
\hline & & $250.5 \pm 15.9$ & 698 & $\mathrm{~S}$ & $\mathrm{~S}$ & - & Thiruvenkadan et al., (2010) \\
\hline & & $331.30 \pm 9.2$ & 917 & - & - & - & Sharma et al., (2010) \\
\hline & & $173.34 \pm 5.59$ & 1637 & $\mathrm{NS}$ & $\mathrm{S}$ & - & Jakhar et al., (2016) \\
\hline
\end{tabular}


Table.2 Means and standard error for reproduction traits of buffaloes

\begin{tabular}{|c|c|c|c|c|c|c|c|}
\hline \multirow[t]{2}{*}{ Sr.No. } & \multirow[t]{2}{*}{ Traits } & \multirow[t]{2}{*}{ Mean \pm SE } & \multirow[t]{2}{*}{$\mathbf{N}$} & \multicolumn{3}{|c|}{ Non genetic factors } & \multirow[t]{2}{*}{ References } \\
\hline & & & & Period & Season & Parity & \\
\hline \multirow[t]{7}{*}{1.} & \multirow[t]{7}{*}{ Service period (days } & $148.40 \pm 8.90$ & 170 & - & - & $\mathrm{S}$ & Swain and Bhatnagar (1983) \\
\hline & & $143.41 \pm 3.97$ & 465 & $S$ & NS & - & Nath (1998) \\
\hline & & $161.10 \pm 13.51$ & 497 & $\mathrm{~S}$ & $\mathrm{~S}$ & - & Suresh et al., (2004) \\
\hline & & $151.46 \pm 3.87$ & 1200 & $S$ & NS & - & Wakchaure (2008) \\
\hline & & $208.23 \pm 9.78$ & 655 & NS & NS & - & Gupta (2009) \\
\hline & & $161.04 \pm 6.03$ & 554 & $S$ & $\mathrm{~S}$ & NS & Patil (2011) \\
\hline & & $187.10 \pm 5.91$ & 1637 & $S$ & $\mathrm{~S}$ & - & Jakhar et al., (2016) \\
\hline \multirow[t]{5}{*}{2.} & \multirow[t]{5}{*}{ Calving interval (days) } & $528 \pm 2.9$ & 2107 & - & - & - & Kuralkar and Raheja (1997) \\
\hline & & $478 \pm 5.1$ & 1164 & $\mathrm{~S}$ & $\mathrm{~S}$ & - & Triveni et al., (2001) \\
\hline & & $488.19 \pm 5.44$ & 1200 & $\mathrm{~S}$ & $\mathrm{~S}$ & - & Wakachaure et al., (2008) \\
\hline & & $532 \pm 5$ & 698 & - & $\mathrm{S}$ & - & Thiruvenkadan et al., (2015) \\
\hline & & $479.47 \pm 4.88$ & 1637 & NS & $\mathrm{S}$ & $\mathrm{S}$ & Jakhar et al., (2016) \\
\hline
\end{tabular}




\section{Dry period}

Dry period is the period during which animal remains out of milk production. So, dry period being non-productive period needs to be reduced to the minimum in order to maximize the profits. Barman (2009), Thiruvenkadan (2011), Singh et al., (2011), Barman et al., (2012), Jakhar et al., (2016) also reported significant effect of period of calving on dry period in different breeds of buffaloes. However, non-significant effect was reported by Kumar (2000) in Murrah buffaloes. Jakhar et al., (2016) reported highly significant $(p<0.01)$ effect of season of calving on dry period in Murrah buffalo. However Kumar (2000), Suresh et al., (2004), Barman (2009) and Barman et al., (2012) in Murrah buffaloes reported non-significant effect of season of calving on dry period.

\section{Reproduction traits}

\section{Service period}

It is the period between calving and the subsequent successful conception. Generally, an optimum period of 60 days is allowed as post-partum rest.

Besides, managemental and environmental factors, it is generally regarded as the function of initiation and regularity of estrus and number of service per conception. Suresh et al., (2004), Godara et al., (2004), Wakchure et al., (2008) and Barman (2009) observed significant effect of period of calving on SP in Murrah buffaloes. While Kumar (2000), Kumar et al., (2005) and Gupta et al.,(2012) reported non-significant effect of period of calving on SP in different breeds of buffaloes. Significant effect of season of calving on dry period was reported by Kumar (2000), Dhirendra et al., (2003), Suesh et al., (2004), Kumar et al., (2005), Jakhar et al., (2016) in Murrah buffaloes,

\section{Calving interval}

Calving interval is the period between two consecutive calvings. Calving interval has direct bearing on both reproduction and production efficiencies. Short calving interval along with early age at first calving are required for better efficiency of milk production. Jakhar et al., (2016) reported significant effect of parity on calving interval in Murrah buffaloes. Kumar (2000), Kumar et al., (2005) and Barman (2009) in Murrah buffaloes reported non-significant effect of period of calving. Gupta et al., (2012), Jakhar et al., (2016) observed no significant effect of period of calving on calving interval in Murrah buffalo. Lundstrom et al., (2007) reported significant influence of period and season of calving on calving interval in Murrah buffalo. Significant effect of season of calving was reported by Dhirendra et al., (2003), Grewal et al., (2003), Suresh et al., (2004), Kumar et al., (2005), Lundstrom et al., (2007), Barman (2009), Jakhar et al., (2016) in buffaloes.

The primary goal of animal breeder is to maximize the rate of genetic improvement through selection and improvement of several traits simultaneously. We want to select animals that have not only good production performance, but also have good health and reproduction.

Genetic improvement through selection in a breeding program depends on the accuracy of identifying genetically superior animals. Selection of dairy animals is generally based on the records of performance traits. The variations in performance traits may be more of environmental nature as opposed to genetics and sampling of population. As per the literature, all important non-genetic factors such as season of calving, period of calving and parity of animals had significant influence on the performance traits in buffaloes. Therefore, adjustment of effect of 
non-genetic factors is important for accurate and unbiased estimates of genetic parameter.

\section{References}

Barman, R.S.D. (2009).Studies on non-genetic factors affecting first lactation and life time performance traits in Murrah buffaloes.M.V.Sc. thesis, H.A.U. India.

Barman, R.S.D., Grewal, S.S., Dalal, D.S., Ahmad, M. and Mahto, D. (2012).Nongenetic factors affecting first lactation production traits in Murrah buffaloes.Indian Vet. J.89(8): 53-55.

Chakraborty, D., Dhaka, S.S., Pander, B.L., Yadav, A.S. and Danpat (2010). Genetic studies on 305 days and test day milk yield records in Murrah buffaloes. Indian J. Anim. Sci.80(8) 720-732.

Chitra, A., Jain, A., and Kumar, M. (2016).Effect of genetic and non-genetic factors on milk yield and milk composition traits in Murrah buffaloes.Ind J Anim Res. 2016; 3188: 15p. DOI: 10.18805/ijar.v0i0f.3785.

Dhar, Y.M. and Deshpande, K.S. (1995). Genetic studies on lactation milk yield and lactation length in Murrah buffaloes. Indian J. Dairy Sci. 48(2).

Dhirendra, H.S., Kumar, P. and Singh, C.V. (2003).Non-Genetic factors affecting some production and reproduction traits in Murrah buffaloes. Indian J. Anim. Res.37: 24-27.

Godara, A., Singh, D. and Grewal.S.S. (2004).Factors affecting production, reproduction and lifetime traits and their association with production life.Indian Buffaloes J.2(1): 23-27.

Grewal, S.S., Yadav, R.S., Sangwan, M.L. and Saini, M.S. (2003).Non-genetic factor affecting the production traits in Murrah buffaloes, proceeding of the $4^{\text {th }}$ Asian Buffalo Congress.Buffalo for food security and rural Employement.Vol. 2 PP-19394.New Delhi, India, 25 Februry 2003.

Gupta, J.P. (2009).Evolving selection criteria using growth and production traits in Murrah buffaloes.M.V.Sc. Thesis. Karnal, Haryana, India: N.D.R.I (Deemed University).

Gupta, J.P., Sachdeva, G.K., Gandhi, R.S. and
Chakaravarty, A.K. (2012). Non-genetic factors influencing growth and production performance in Murrah buffaloes. Indian J. Dairy Sci.65(3).

Gurung, B.S. and Johar, K.S. (1982). Studies on factors affecting lactation yield in Murrah buffaloes. Indian Vet. J. 59: 521-526.

Jakhar, V., Vinayak, A.K. and Singh, K.P. (2016). Genetic evaluation of performance attributes in Murrah buffaloes. Haryana Vet. 2016; 55(1): 66-9p.

Jamuna, V., Gupta, A.K., and Chakravarty, A.K. (2016). Leptin gene polymorphism in association with lactation milk yield in Murrah buffaloes. Ind JAni Sci.; 86(1): 95$7 \mathrm{p}$

Joshi, B.K. and Tripathi, V.N. (1987). Ranking of buffalo bulls based on certain measures of efficiency of milk production and economic merit. Indian J. Anim. Prod. Mgmt.3: 124128.

Katneni, V.K (2007). Studies on genetic persistency of milk production in Murrah buffaloes. Ph.D. Thesis. Karnal, Haryana, India: NDRI (Deemed University).

Kumar, A. (2000). Genetic studies on first lactation traits in Murrah buffaloes. M.V.Sc. thesis, H.AU., Hisar, India.

Kumar, D. K., Reddy, C. E., Gupta, B. R. and Satyanarayana, A. (2003). Effect of year, season and lactation order on the performance of Ongole cattle. Indian $J$. Anim. Sci. 73(11): 1289-1290.

Kumar, D., Verma, S.B., Singh, S.R., Mandal, K.G. and Pandey, R.P. (2005). Effect of genetic and non-genetic factors on dry period and age at first calving in Hariana and its crosses. Indian J. Anim. Health.44(2): 99-102.

Kumar, M., Vohra, V. and Ratwan, P. (2016). Estimates of genetic parameters for fat yield in Murrah buffaloes. Veterinary World.2016; 9(3): 295-8p

Kumar, V., Chakravarty, A.K., Patil, C.S., Valsalan, J., Sharma, R.K. and Mahajan, A. (2014). Genetic studies of first lactation production traits of Murrah buffaloes under network project of buffalo improvement. Indian Vet. J. 91(07): 26-28.

Kuralkar, S.V., Raheja, K.L.(1997). Relationship among early performance, lifetime 
production \& reproduction traits in Murrah buffaloes.Ind J Anim Sci.; 67(9): 798-801p.

Lundstrom, K., Abeygunawardena, H., De Silva, L.N.A. and Perera, B.M.A.O. (2007). Environmental influence on calving interval and estimates of its repeatability in the Murrah buffalo in Sri lanka.International Committee Anim. Recording (ICAR). 10.1016/0378-4320.

Nath, M. (1998).Breeding value evaluation for milk production in Murrah buffaloes. M.Sc. Thesis, NDRI, Deemed Univ. Karnal, India.

National Dairy Development Board.Annual Report (2014-15). India: National Dairy Development Board; 2015. Available from: www.nddb.coop

Pandey, H., Tomar,AKS.,Upadhyay, D. (2015). Effect of environmental factors on first lactation milk yield in Murrah buffaloes.Buffalo Bulletin.; 34(4): 459-64p.

Patil, C.S.(2011).Genetic evaluation of fertility in Murrah buffaloes.MVSc. Thesis.Karnal, Haryana, India: NDRI (Deemed University).

Pawar, H.N., Kumar, G.V.P.P.S.R. and Narang, R. (2012).Effect of Year, Season and Parity on Milk production traits in Murrah buffaloes.J. Buff. Sci., 1: 122-125.

Prakash, A. and Tripathi, V.N. (1987b). Factors affecting production characters of Murrah buffaloes.Indian J. Dairy Sci.43: 178-180.

Sahoo, S., Singh, A., Gupta, A.K., et al., Estimation of genetic parameters of weekly test-day milk yields and first lactation 305day milk yield in Murrah buffaloes. Vet World. 2014; 7(12): 1094-8p

Sharma, R.C., Khanna, A.S. and Sethi, R.K. (2010). Effect of non-genetic factors on early production performance traits in Murrah buffaloes.IndVety Jour.; 87(2): $152-5 p$

Singh, T.P., Singh, R., Singh, G., Das, K.S. and Deb, S.M. (2011).Performance of production traits in Nili-Ravi buffaloes.Indian J. Anim. Sci. 81(12): 12311238.

Suresh, R., Bidarkar, D.K., Gupta, B.R. and Sudhakar, K. (2004).Production and reproduction performance of Murrah buffaloes. Indian J. Anim. Sci.74: 854-857.

Swain, S.N. andBhatnagar, D.S. (1983).Reproduction and production traits in Murrah buffaloes.Ind J Dairy Sci.; 36: 382-6p

Tailor,.SP., Jain, L.S. and Tusavara, M. (1992).Analysis of milk yield, lactation length and dry period in Surti buffaloes.Ind J Anim Sci. 1992; 62(5): 479-81p.

Thiruvenkadan, A.K. (2011). Performance of Murrah buffaloes at coastal region of Tamil Nadu, India. Indian J. Anim. Sci.81(10): 1080-1083.

Thiruvenkadan, A.K., Panneerselvam, S. andMurali, N. (2015). Study on ages at first mating and calving of Murrah buffaloes in hot and humid climate of Tamil Nadu, India. Ind J Anim Res.; 49(5): 591-4p

Thiruvenkadan, A.K., Panneerselvam, S.,Rajendrean, R. and Murali, N. (2010). Analysis on the productive and reproductive traits of Murrah buffalo cows maintained in the coastal region of India. Appl. Anim. Husb. Rural Develop.3: 1-5.

Triveni, D.,Bhushan, B. and Kumar, S. (2001).Genetic parameters of first lactation performance traits in Murrah buffaloes.Ind J Anim Sci.; 71(4): 394-5p

Wakchaure, R.S., Amit, K. Sachdeva and Gandhi, R.S. (2008).Time series analysis of first lactation trait in Murrah buffaloes. Indian J. Dairy. Sci.61: 374-376.

Yadav, B.S., Yadav, M.C., Khan, F.H. and Singh, A. (2002).Murrah buffaloes-11.First lactation yield and first lactation period. Buffalo Bulletin.21(3): 51-54.

\section{How to cite this article:}

Vikram Jakhar, A.K. Vinayak and Singh, K.P. 2017. Effect of Non-genetic Factors on Performance Traits of Murrah Buffaloes: Review. Int.J.Curr.Microbiol.App.Sci. 6(11): 42484255. doi: https://doi.org/10.20546/ijcmas.2017.611.499 